Original Research Paper

\title{
Pelatihan Pembuatan Urea Molases Blok (Umb) Sebagai Suplemen Sapi Pada Peternak Sapi Potong Di Dusun Gading, Desa Montong Betok, Kecamatan Montong Gading Kabupaten Lombok Timur
}

\author{
Rudiman Maulana ${ }^{1}$, Dede Muhsan Hadi ${ }^{1}$, Eni Hariani ${ }^{1}$, Elfin Tranado' ${ }^{1}$ Febilia Andrayani ${ }^{1}$, Ahmad \\ Raksun $^{2}$
}

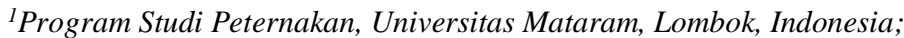

${ }^{2}$ Program Studi Pendidikan Biologi, FKIP, Universitas Mataram, Lombok, Indonesia;

https://doi.org/10.29303/jpmpi.v3i2.658

Sitasi: Rudiman, M., Hadi, D. M., Hariani, E., Tranado, E., Andrayani, F., \& Raksun, A. (2021). Pelatihan Pembuatan Urea Molases Blok (Umb) Sebagai Suplemen Sapi Pada Peternak Sapi Potong Di Dusun Gading, Desa Montong Betok, Kecamatan Montong Gading Kabupaten Lombok Timur. Jurnal Pengabdian Magister Pendidikan IPA, 4(2)

\section{Article history}

Received: 05 Januari 2021

Revised: 19 Februari 2020

Accepted: 05 April 2021

*Corresponding Author:

Rudiman Maulana, Program

Studi Kehutanan, Universitas

Mataram, Lombok, Indonesia;

Email:

ahmadunram@unram.ac.id

\begin{abstract}
Pertambahan penduduk Negara Kesatuan Republik Indonesia yang terus meningkat menyebabkan terjadinya penurunan luas lahan pertanian yang disebabkan oleh adanya alih fungsi lahan peretanian menjadi wilayah pemukiman penduduk. Penurunan luas lahan pertanian berdampak terhadap ketersediaan produk hijauan yang selama ini dimanfaatkan masyarakat sebagai pakan ternak. Berkurangnya produk hijauan mendorong masyarakat untuk memanfaatkan limbah pertanian sebagai pakan ternak. Limbah pertanian memiliki kualitas yang lebih rendah dibandingkan dengan pakan konvensional. Dalam upaya meningkatkan dan mencukupi nutrisi yang kurang pada pakan maka perlu diberikan suplemen tambahan sehingga nutrisi ternak bisa tercukupi. Salah satu suplemen yang bisa digunakan adalah urea molases blok. Urea molases blok merupakan suplemen ternak ruminansia untuk meningkatkan kecernaan pakan yang berkualitas rendah, mengatasi kekurangan nutrisi, mineral dan meningkatkan nafsu makan ternak. Dengan demikian pemberian pakan tambahan berupa UMB dapat meningkatkan produktivitas ternak. Pelatihan pembuatan UMB sudah dilakukan pada peternak sapi yang berdomisili di Dusun Gading Desa Montong Betok Kabupaten Lombok Timur. Peternak sapi yang menjadi peserta kegiatan merespon baik terhadap pelaksanaan pelatiahan pembuatan UBM. Melalui pelatihan tersebut diharapkan masyarakat dapat membuat UBM untuk mengembangkan usaha peternakan sapi.
\end{abstract}

Keywords: Pelatihan pembuatan urea molases blok; Suplemen Sapi

\section{Pendahuluan}

Permasalahan utama yang dihadapi oleh peternak di Indonesia antara lain yaitu ketersediaan lahan pertanian yang terus berkurang dari tahun ke tahunnya, akibatnya berdampak terhadap sektor peternakan, menyebabkan berkurangnya ketersediaan pakan yang berkualitas. Suprio (2013) menyatakan bahwa produksi dan produktivitas ternak sapi di Indonesia pada umumnya dipengaruhi oleh kualitas dan kuantitas pakan hijauan. Kendala penyediaan pakan hijauan diantaranya, luas lahan yang semakin sempit dan produk hijauan yang dibatasi oleh musim. Kenyataan tersebut mengakibatkan peternak memberikan limbah pertanian sebagai pakan utama untuk menggantikan pakan konvensional sehingga terjadi penurunan produktivitas pada ternak. Pertambahan berat badan pada ternak dapat ditentukan oleh jumlah pakan yang dikonsumsi, manajemen pemeliharaan dan genetik dari ternak 
tersebut. Menurut Tilman et al (1991), pakan merupakan faktor yang mendominasi kecepatan pertambahan berat badan, sebab pakan lebih banyak mempengaruhi pembentukan jaringan tubuh secara alamiah. Supratman dan Iwan (2001) menyatakan bahwa pertambahan berat yang maksimal pada ternak dapat dicapai apabila pakan yang diberikan tercukupi, baik nilai gizi maupun kuantitas pakan. Sapi merupakan ternak ruminansia yang memiliki kemampuan untuk memanfaatkan pakan berkualitas rendah dan mengubahnya menjadi produk yang memiliki nilai gizi dan ekonomi tinggi.

Desa Montong Betok merupakan salah satu desa di kecamatan Montong Gading Kabupaten Lombok Timur, Provinsi Nusa Tenggara Barat. Montong Betok memiliki luas wilayah sekitar 393 Hektar dengan jumlah penduduk 851 jiwa. Mayoritas penduduk Desa Montong Gading bekerja sebagai petani yang sebagaian besar menanam padi dan menghasilkan limbah berupa jerami padi. Jerami padi merupakan salah satu limbah pertanian yang umum diberikan untuk pakan ternak sapi, akan tetapi penggunaan jerami padi sebagai pakan ternak memiliki keterbatasan karena karakteristik dinding selnya. sebagai limbah tanaman tua, jerami padi telah mengalami lignifikasi lanjut, menyebabkan terjadinya ikatan komplek antara lignin, selulosa dan hemiselulosa yang sulit dicerna (Eunt et al.,2006).

Upaya untuk meningkatkan dan mencukupi nutrisi yang kurang dari pakan maka perlu diberikan suplemen tambahan sehingga nutrisi ternak bias tercukupi. Urea molases block merupakan pakan tambahan untuk ternak ruminansia seperti sapi, urea molases block juga disebut sebagai permen ternak ruminansia yang tersusun dari molases sebagai sumber energi bagi ternak, molases merupakan produk samping pengolahan tebu dalam pembuatan gula, biasanya dimanfaatkan sebagai sumber energi karena molases mengandung glukosa dan asam organik, urea sebagai sumber nitrogen, kapur dan garam sebagai sumber mineral, dedak padi dan dedak jagung sebagai sumber protein. UMB berbentuk padat yang kaya akan zat-zat makanan, dibuat dari bahan utama berupa molases. Menurut Nista et al. (2010) urea molases blok (UMB) merupakan suplemen tambahan untuk ternak ruminansia yang kaya akan manfaat, mengandung zat-zat gizi yang dibutukan ternak. Pemberian suplemen atau pakan pelengkap dapat meningkatkan efisiensi pencernaan pakan sehingga dapat meningkatkan produksi ternak (Hatmono dan Hastoro, 1997), oleh sebab itu pelatihan pembuatan urea molases blok sebagai pakan tambahan di Dusun Gading, Desa Montong Betok diharapkan dapat membantu peternak untuk meningkatkan produksi dari ternaknya dan mningkatkan pendapatan peternak.

\section{Metode}

Metode yang digunakan pada program pelatihan pembuatan urea molases block adalah demplot atau sosialisasi dan on-job training (praktik secara langsung) yang ditunjukan untuk meningkatkan pengetahuan, skill (keterampilan) dan sikap kelompok sulit mekar dalam mengoptimalikan pemeliharaan ternak, ada beberapa tahapan kegiatan yang dilaksanakan dalam pelatihan pembuatan UMB antara lain yaitu: 1). Perencanaan dan penentuan target sasaran pelatihan pembuatan UMB, 2). Pembuatan surat undangan dan pengantaran surat ke kawil Dusun Gading, 3). Persiapan alat dan bahan yang akan digunakan dalam pelatihan pembuatan UMB, 4). Pelaksanaan pelatihan pembuatan UMB, 5). Penyerahan hasil pembuatan UMB ke peternak.

\section{Hasil dan Pembahasan}

Salah satu tujuan pemeliharaan sapi potong adalah tercapainya produktivitas dari ternak, untuk mencapai itu maka dibutuhkan pakan yang memiliki gizi yang dibutuhkan ternak. Pakan sapi potong terdiri dari hijauan sebagai pakan utama dan konsentrat sebagai pakan tambahan. Hijauan merupakan pakan yang mengandung serat kasar tinggi dan lebih sulit dicerna dibandingkan dengan konsentrat, sedangkan pakan konsentrat mengandung energi dan protein tinggi dan kadar serat yang rendah. Peternak sapi potong di Dusun Gading, Desa Montong Betok umumnya menggunakan hijauan sebagai pakan utama ternaknya, salah satu hijauan yang umum diberikan yaitu jerami padi. Jerami padi merupakan hijauan yang mengandung serat kasar tinggi dan tidak mudah tercerna, hal ini tentunya belum mencukupi semua kebutuhan nutrisi yang dibutuhkan ternak, untuk mencapai produktivitas yang tinggi maka dibutuhkan tambahan unsu-unsur mikro seperti vitamin dan mineral. 
Urea molases blok merupakan pakan suplemen yang mengandung unsur-unsur mikro tersebut. Urea molases blok adalah pakan suplemen bagi ternak ruminansia kaya akan zat-zat makanan yang dibutuhkan oleh ternak ruminansia seperti sapi, urea molases blok memiliki bentuk padat, terbuat dari bahan utama berupa molases (tetes tebu) sebagai sumber energi, urea sebagai sumber nitrogen, bahan lain seperti garam, kapur sebagai pelengkap zat-zat mineral, serta bahan pengisi dan penyerap molases berupa dedak padi dan dedak jagung. Parakkasi (1999) menyatakan bahwa urea molases blok merupakan pakan yang didalamnya mengandung urea dan molases Pembuatan suplemen UMB dapat dibuat dengan menggunakan formulasi yang beragam, tergantung pasokan dan ketersediaan bahan yang digunakan sebagai bahan pembuatan UMB. Pada pelatihan pembuatan urea molases blok di Dusun Gading, Desa Montong Betok digunakan bahan-bahan seperti molases, urea, dedak padi, dedak jagung, kapur, dan garam, utuk table formulasinya dapat dilihat pada table di bawah ini.

Tabel 1. Bahan dan presentase pembuatan UMB

\begin{tabular}{|c|c|}
\hline Bahan & $\begin{array}{c}\text { Persentase } \\
\text { bahan/(kg) }\end{array}$ \\
\hline Molases & $25 \%$ \\
Dedak padi & $30 \%$ \\
Dedak & $25 \%$ \\
jagung & $7 \%$ \\
Urea & $6 \%$ \\
Kapur & $7 \%$ \\
Garam dapur & \\
\hline \multicolumn{2}{|r|}{ Metode yang digunakan dalam }
\end{tabular}

pembuatan suplemen UMB ini yaitu cara dingin, langkah ini merupakan langkah sederhana bagaimana molases dicampur dengan urea dan bahan-bahan lainnya sampai adonan merata lalu dipadatkan, kemudian dicetak. Alat yang digunakan antara lain, cetakan UMB, ember, bak karet, dan terpal. Tahap pembuatannya yaitu : 1) timbang bahan sesuai presentase bahan yang telah ditentukan, 2) tumbuk halus urea agar mudah larut, 3) untuk pembuatan bahan larut, tuangkan molases kedalam ember tambahkan dengan urea yang sudah ditumbuk dan garam, 4) campur rata dedak padi, dedak jagung, dan kapur, 5) tambahkan bahan larut sedikit demi sedikit kedalam campuran dedak padi, 5) aduk semua bahan sampai tercampur rata, 6) masukan kedalam cetakan kemudian ditumbuk sampai padat dan keras, untuk lebih jelasnya hasil pembuatan UMB dapat dilihat pada gambar dibawah ini.

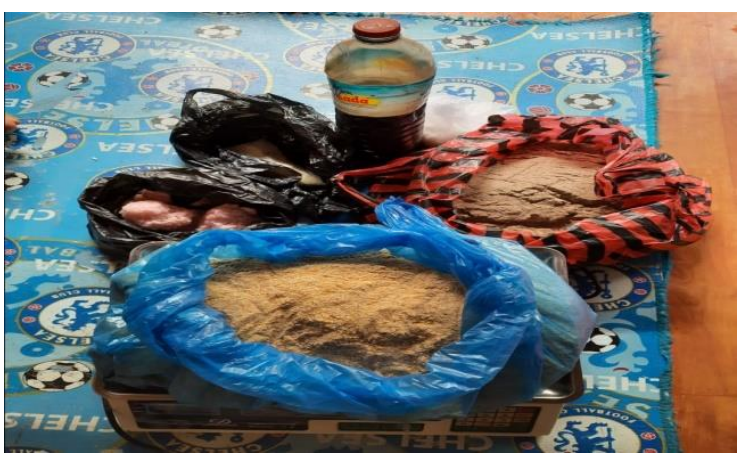

Gambar 1. Bahan pembuatan UMB

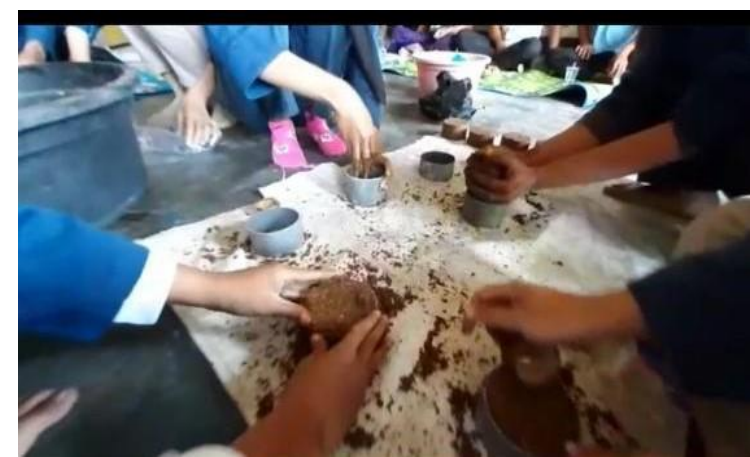

Gambar 2. Pembuatan UMB

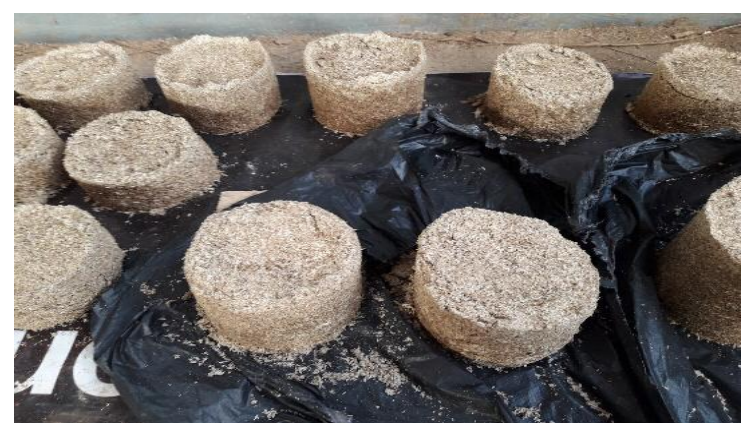

Gambar 3. Urea Molases Blok

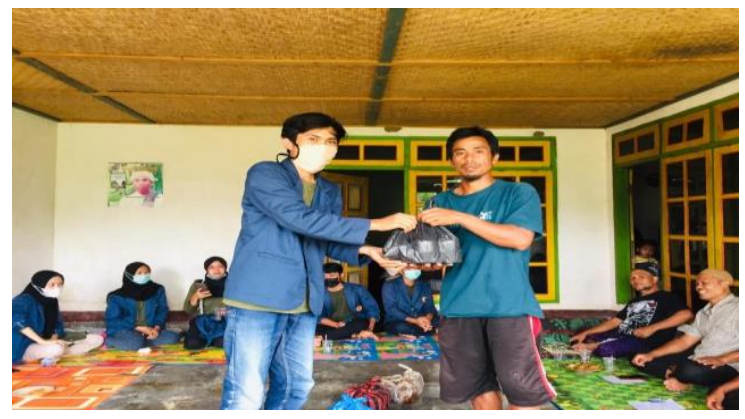

Gambar 4. Penyerahan UMB ke peternak 


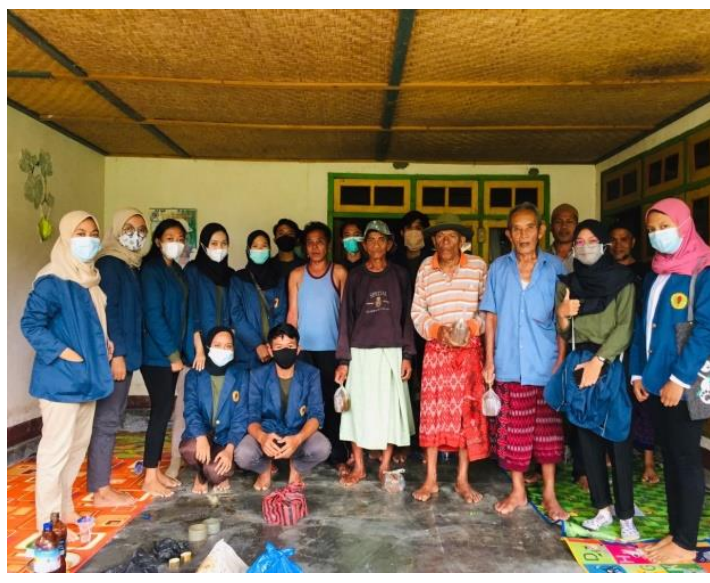

Gambar 5. Peternak dan mahasiswa KKN

UMB (urea molases block) dapat digunakan untuk ternak-ternak yang dikandangkan ataupun yang digembalakan, UMB berbentuk padat dank keras (lihat gambar 1) dengan aroma serta rasa molases yang dapat merangsang ternak untuk memakannya, dengan demikian, ternak akan selalu menerima asupan protein, energi dan beberapa mineral secara kontinyu. Manfaat mengkonsumsi UMB adalah dapat meningkatkan produktivitaas ternak. Menurut hasil penelitian, pemberian UMB dapat meningkatkan kecernaan dan konsumsi zatzat makan dari bahan pakan berserat tinggi yang diberikan pada ternak. Hatmono dan Indriyadi (1997) menerangkan bahwa manfaat UMB yaitu meningkatkan produktivitas ternak melalui peningkatan sintesa protein oleh mikroba dalam rumen, peningkatan kecernaan pakan dan peningkatan konsumsi pakan yang semuanya itu akan memberikan keseimbangan yang lebih baik antara suplai asam amino dan energi dan kebutuhan ternak untuk tumbuh, berproduksi, hal ini meningkatkan populasi mikroorganisme rumen sehingga kebutuhan serat kasar sebagai media hidupnya akan meningkat pula, sehingga akan merangsang lemak untuk mengkonsumsi bahan pakan lebih banyak dari keadaan normalnya, dengan meningkatnya konsumsi pakan maka produksi ternak (daging) akan meningkat pula. Dosis pemberian UMB menurut Hatmono dan Indriyadi (1997), yaitu 120 gr/ekor/hari untuk ternak kecil (kambing dan domba). Pakan ternak ini dikonsumsi dengan cara menjilat dan diberikan dengan cara meletakkan di tabung bamboo atau kotak pakan, suplemen ini diberikan pada pagi hari dengan jumlahnya sesuai dengan tingkat konsumsi yang dianjurkan pada setiap jenis ternak, walaupun ukuran UMB melebihi kebutuhan maka biasanya ternak akan membatasi sendiri.

\section{Kesimpulan}

Berdasarkan kegiatan yang telah dilaksanakan dapat disimpulkan bahwa pelatihan pembuatan urea molases blok (UMB) merupakan salah satu upaya untuk meningkatkan dan mencukupi nutrisi dan zat-zat gizi yang kurang dari pemberian pakan yang memiliki kualitas gizi rendah. Peternak sapi di Dusun Gading, Desa Montong Betok merespon baik terhadap kegiatan ini. Pembuatan UMB dapat membantu peternak untuk meningkatkan nafsu makan dan daya cerna dari ternaknya sehingga dapat meningkatkan produktivitas ternak.

\section{Ucapan Terima Kasih}

Terima kasih sebesar besarnya kami ucapkan kepada seluruh pihak yang telah membantu dalam menjalankan kegiatan pengabdian kepada masyarakat ini, diantaranya: (1) masyarakat Dusun Gading Desa Montong Betok atas kerjasama dan partisipasinya dalam pelaksanaan kegiatan ini, (2) LPPM UNRAM yang telah menfasilitasi pelaksanaan KKN mahasiswa Universitas Mataram

\section{Daftar Pustaka}

Eun JS, Beauchemin KA, Hong SH, Bauer MW.2006. Exogenous enzymes added to untreated orammoniated rice straw:Effect on in vitro fermentationcharacteristic and degradability. J AnimSci and Tech 131: 86101

Hatmono, H. dan I. Hastoro, 1997. Urea Molases Blok Pakan Supleme Ternak Ruminansia. Trubus Agriwidya. Ungaran.

Nista D, Natalia H, Taufik A. 2010. Teknologi Pengolahan Pakan. Palembang. Direktorat Jendral Bina Produksi Peternakan. Hlm. 2-3

Parakkasi, A. 1999. Ilmu Nutrisi dan

Makanan Ternak Ruminansia. UI Press. Jakarta. 
Supratman dan Iwan. 2001. Manajemen Pakan Sapi Potong. Pelatihan Wirabisnis Feedlot Sapi Potong. Fakultas Peternakan,UNPAD. Bandung

Suprio.G, 2013. Membuat Pakan Ternak dan Kompos Dari Limbah Organik. PT Agromedia Pustaka.Jakarta Selatan.

Tillman, A. D., H. Hartadi, S. Reksohadiprodjo, S. Prawirokusumo, dan S.Lebdosoekojo, 1991. Ilmu Makanan Ternak Dasar. Gadjah Mada University Press. Yogyakarta. 